\title{
WILDFIRE DYNAMICS AND ITS EFFECTS ON THE FOREST RESOURCES AND PUBLIC PROPERTY IN NEPAL
}

\author{
Krishna Bahadur Bhujel $^{1 *}$, Rejina Maskey Byanju ${ }^{1}$, Ambika P. Gautam ${ }^{2}$ \\ ${ }^{1}$ Central Department of Environmental Science, Tribhuvan University, Kirtipur, Kathmandu, Nepal \\ ${ }^{2}$ Kathmandu Forestry College, Kathmandu, Nepal \\ *Corresponding author: bhujelkb@gmail.com
}

(Received: July 11, 2018; Revised: December 4, 2018; Accepted: December 8, 2018)

\begin{abstract}
NASA (National Aeronautics and Space Administration) has detected several intensive wildfires from the local to global level in 2016. However, deeper study on the dynamics of wildfire and its consequences are still inadequate. This study was carried out to find wildfire dynamics and its effects on the forest resources and public property in Nepal. Moderate Resolution Imaging Spector-Radiometer (MODIS) was used for active fire data of 2016 in Nepal. Wildfire-related national and international published articles, report, website and media were reviewed. Data were analyzed using ArcGIS and MS Excel. The result showed an abnormal wildfire incidence areas in 2016, adverse effect on the forest resources and public property. One hundred forty burnt days were recorded. Density of wildfire incidence and burnt area were found to be 0.09 number and 3.4 hectares per $\mathrm{km}^{2}$, respectively, which was around $33 \%$ more than of the last 15 years. The huge forest resources and its tangible as well as intangible services were lost during the year of 2016. Loss of forest resources account for about NRs 11,750,000 (US\$ 107,798) as per local market price for the year. Total eleven people were killed and over hundred people injured. The findings of the present study will be useful baseline information for implementers, researchers and decision-makers in future.
\end{abstract}

Keywords: Burnt area, Density, Wildfire incidence, Wildfires day

\section{INTRODUCTION}

Wildfire is a critical disturbance factor in the forest ecosystems, which acts as a double-edged sword in the natural circumstance. It is considered an important part of ecosystem services, providing nutrients and recycling material and is also one of the important disturbance factors in boreal forests (Shorohova et al. 2011, de Groot et al. 2013). Wildfires also play an important role in several atmospheric chemistry and climate feedback mechanisms (Fiore et al. 2012). The impacts of wildfires on human society are largely determined by population growth and spatial distribution (Knorr et al. 2016). According to Global Forest Resources Assessment (FAO 2010), around 19.8 million hectares of forests are affected by fire annually in 118 countries of the world. Moreover, 3.73 million hectares of forests are affected annually in India (Satendra \& Kaushik 2014). Wildfire occurrence and severity have been increasing in recent decades and will continue to increase due to climate change (Doerr \& Santin 2016) and it showed that approximately $0.4 \%$ of the total land surface was recorded as the burnt area per year in the world (Randerson et al. 2012). Giglio et al. (2013) depicted that global area was nearly $350 \mathrm{MHa}$ annually.

Tropical Asia has experienced the highest biomass burning region in Asia due to the extreme climatic conditions (Streets et al. 2003). Wildfire behavior is influenced by the distribution of forest resources (fuels), topography and favorable environmental conditions
(Parisien \& Moritz 2009). According to India State of Forest Report (MEF/India 2011), more than 95 percent of the forest fires in the Indian were anthropogenic causing wide range of adverse ecological, economic and social impacts. NASA (Lynn 2017) data has recorded warmer year in 2016 than the mid- $20^{\text {th }}$ century. It has been reported to be responsible for the increase of $1.78^{\circ} \mathrm{F}(0.99$ ${ }^{\circ} \mathrm{C}$ ) in average global temperatures.

Global temperature has been increased by approximately $0.2{ }^{\circ} \mathrm{C}$ per decade over the last three decades (Hansen $e t$ al. 2010). The study done by Kothawale et al. (2010) highlighted that the mean temperature during the premonsoon season (March-May) was increasing by $0.42{ }^{\circ} \mathrm{C}$ per 100 years. Hartmann et al. (2013) noted that the warming trend was increased globally, which could be associated with variations in the climate system. Annual temperature was increased in India as well (Rohini et al. 2016). The extreme severe heat waves $\left(>40{ }^{\circ} \mathrm{C}\right)$ events were recorded on 11 April and 21 May, 2016 which were rare events (Singh et al. 2017). The changing scenario of temperature and precipitation is resulting in the increase in the number of wildfires (Negi et al. 2012).

In general, months between March-May were noticed as the driest season in Nepal (GoN/MoE 2010). The record of fire incidence has been increasing annually in Nepal. Parajuli et al. (2015) showed that wildfire result in loss of natural vegetation as well as the destruction of human settlements. MODIS sensors recorded 29844 wildfire incidences in Nepal from 2003 to 2013. Based on > $50 \%$ 
confidence level, 12269 fire incidences occurred within forest, grasslands, shrub lands, and outside protected areas of Nepal (Matin et al. 2017). Moreover, Jenner (2017) mentioned that there was higher smoke and wildfire in a satellite image of Nepal for year 2016 and hence it results in adverse effects on the forest resources and public property. In this context, several questions were raised regarding the noticeable wildfire events in the year of 2016 for the research. For example; what could be the pattern of wildfire incidence and burnt area in 2016, what will be its consequences in forests and public property? This research was carried out to address these questions showing the wildfire incidence, burnt area, burning days, density of wildfire and its effects on the forest and public property for 2016 in Nepal.

\section{MATERIAL AND METHODS}

\section{Study area}

The study area covers the entire Nepal, which situated between latitude $26^{\circ} 22^{\prime} \mathrm{N}$ and $30^{\circ} 27^{\prime} \mathrm{N}$ and longitude $80^{\circ} 40^{\prime} \mathrm{E}$ and $88^{\circ} 12^{\prime} \mathrm{E}$ with area of $147181 \mathrm{~km}^{2}$. It is divided into five physiographic zones namely High Himalayan, High Mountains, Middle Mountains, Siwalik and Terai (Fig. 1). Country exhibits mostly mountainous terrain with an elevation ranging from $58 \mathrm{~m}$ to $8848 \mathrm{~m}$ above mean sea level (amsl) at Mount Everest. Nepal is considered biodiversity hotspots, as it is home for 35 forest types, 75 vegetation types and 118 ecosystems (Chettri et al. 2008). However, these ecosystems are facing challenges due to natural and anthropogenic induced climate change and wildfire. Total forest including other wooded lands comprised $44.74 \%$ (6.61 million ha) in the country (DFRS 2015).

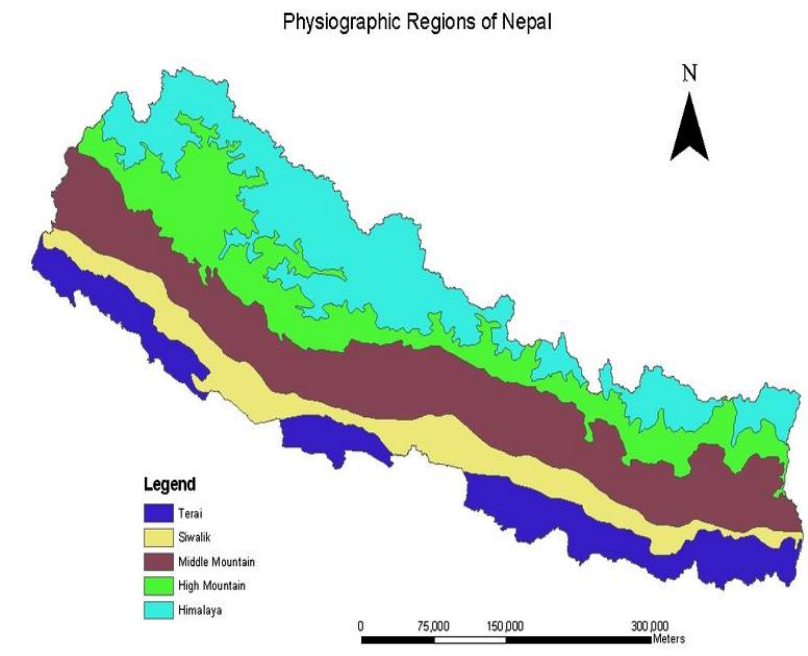

Fig. 1. Physiographic regions of Nepal

Dobremez (1972) have identified 118 ecosystems and classified Nepal into 4 domains and 11 sub-levels and provided six vegetation categories based on an altitudinal classification (bio-climatic zones) as; tropical (below
1,000 $\mathrm{m}$ altitude), sub-tropical (1,000 to 2,000 m altitude), temperate (2,000 to $3,000 \mathrm{~m}$ altitude), sub-alpine (3,000 to 4,000 $\mathrm{m}$ altitude), alpine (4,000 to 5,000 m altitude) and nival (above 5,000 $\mathrm{m}$ altitude).

Four climatological seasons has been divided as; hot and dry pre-monsoon period (March-May), the summer monsoon (June-September) which is characterized by high humidity and precipitation, the post-monsoon (October-November) with reduced rainfall, and dry and cold winter period (December-February) (Kansakar et al. 2004). Terai and middle mountain regions of Nepal are gradually experienced of the increasing temperatures due to climate change. Specifically, it was reported that about $3{ }^{\circ} \mathrm{C}$ is increased during the summer months over the last few decades that are expected to rise by $1.48{ }^{\circ} \mathrm{C}, 2.88^{\circ} \mathrm{C}$ and $4.78{ }^{\circ} \mathrm{C}$ by 2030, 2060 and 2090, respectively (Pradhan et al. 2013). A significant positive trend in annual and seasonal maximum temperature was reported (DHM, 2017). This changing scenario of temperature and precipitation might be responsible for increasing in the number of forest fires in future, indicating Nepal to be vulnerable to wildfire.

\section{Data sources and collection methods}

The active fire data from the Moderate-resolution Imaging Spectro-radiometer (MODIS) device on NASA's Terra and Aqua satellites date of 2016 was used as the main data source. The resolution of MODIS image is $1 \mathrm{~km} \times 1 \mathrm{~km}$ which records four times fire incidence observations per day basically in 1030 and 2200 hours from Terra and 0130 and 1330 hours from Aqua. During this period, a wildfire incidence in 2016 was driven from MODIS products with confidence levels of 1-100\%. It filtered out the records less than $50 \%$ confidence level and counted only over $50 \%$ confidence level. The coordinates of wildfire points and the date of wildfire incidence were obtained free of cost from the MODIS active fire products (version 5.1). These point data were achieved from https://firms.modaps.eosdis.nasa.gov/download/ in the form of shape-files which were further analyzed in Arc Map 10.1.

MODIS also provide the data of a burnt area in Geo-TIFF format images with clearly distinguished burnt area pixels (including burnt-date information) from other adjacent pixels. The monthly level 3 gridded $\left(500 \times 500 \mathrm{~m}^{2}\right)$ burnt area product (MCD45A1) was downloaded from the ftp server (ftp://ba1.geog.umd.edu/Collection5/TIFF/Win18/). Burnt area pixels within the study area were extracted from TIFF images and processed in Arc Map 10.1 to calculate the burnt area. The accuracy of the burnt area and number of wildfire incidence was checked by comparing with the general accuracy statement of MOD14 product performance and direct field observation. Moreover, the desktop review of the related literature was carried out to find out the wildfire incidence and burnt 
area. Besides, the published and unpublished newspaper, article, reports were reviewed.

\section{Data analysis}

The collected data of wildfire incidence and burnt areas of 2016 was analyzed using Microsoft Excel. The linear regression model was used to find the dynamics of wildfire events and its effects on forest resources and public property sector. Wildfire point was estimated to count the polygon. Burnt area pixels within the study area were then extracted from the TIFF images using clip function processed in Arc Map 10.1. Again clip function was applied to extract Nepal shape-file and then calculated the burnt area.

\section{RESULTS}

\section{Wildfire incidence and burnt area}

The wildfire incidence (Fig. 2) and burnt area (Fig. 3) were recorded higher across the country, basically concentrated in the Province No. 5 and 7 of Nepal. The low land of the forests has noticed higher numbers of fire ignitions, indicating high wildfire prone areas of Nepal. Furthermore, the result showed that there were 5630 wildfire incidences and 222046 ha burnt forest area in 2016. The month of April was noticed with highest wildfire incidence and burnt area, with $72 \%$ and $81 \%$ coverage, respectively and it was followed by March, May, February and January as shown in Fig. 4.

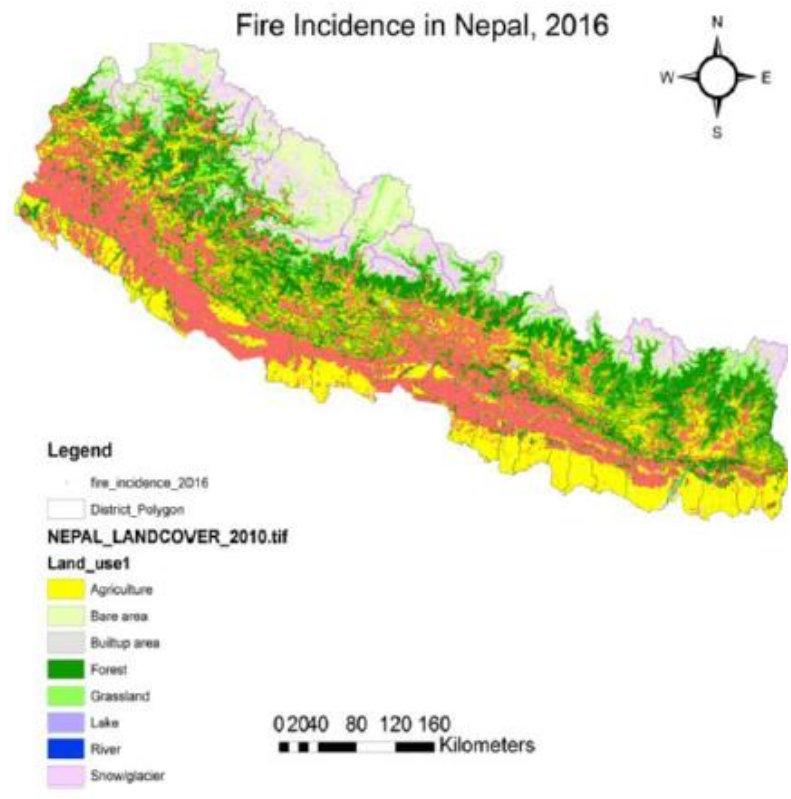

Fig. 2. Wildfire incidence in Nepal in the year of 2016

\section{Seasonal patterns of wildfire incidence and burnt area}

The wildfire incidence and burnt area varied according to climatological seasons. The result showed that premonsoon had higher wildfire incidence and burnt area than other seasons. It covered approximately $90 \%$ wildfire incidence and $92 \%$ burnt area out of the total events (Fig. 5). It is due to thick, hot and dry fuel. It was followed by winter season $(7 \%)$. The summer monsoon and post monsoon had lower wildfire events.

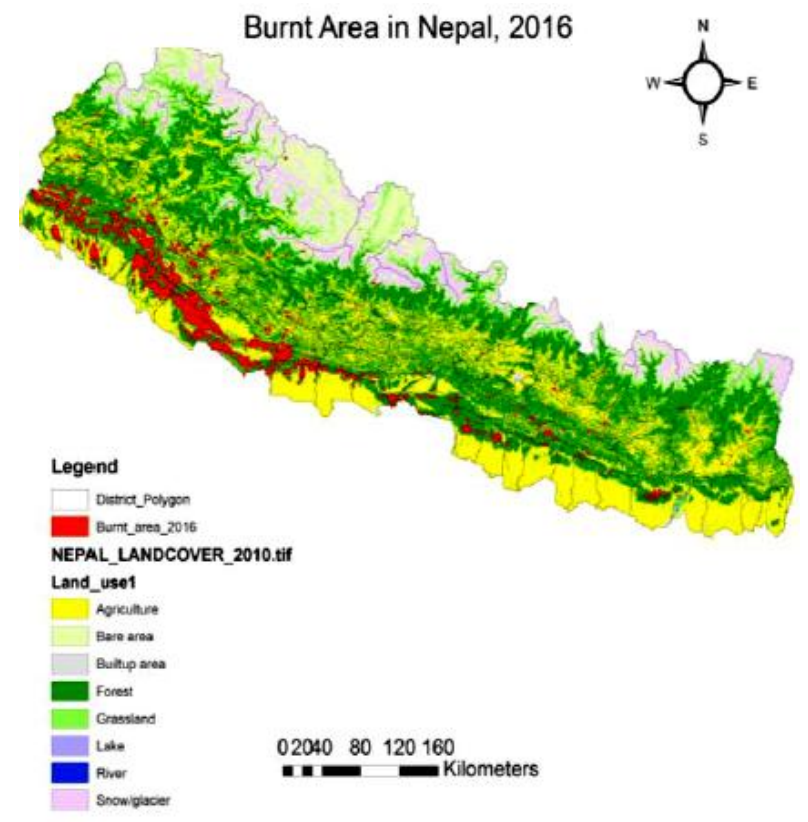

Fig. 3. Wildfire burnt area in the year of 2016

\section{Wildfire incidence days}

Total 140 days were recorded as wildfire incidence in 2016. The wildfire days noticed minimum 0 and maximum 25 in each month. Out of the total wildfire days, $41 \%$ wildfire days were recorded in active fire season of March, April and May months. An average of 40 numbers of wildfire incidence and 1586 hectares burnt area recorded per day. An average of 12 wildfire day, 469 numbers of wildfire incidence and 18504 ha burnt area were recorded in a month in 2016 (Table 1). The maximum wildfire incidence (3991 number of incidence) and burnt area (7528 ha) was noticed in April.

\section{Densities of wildfire incidence and burnt area}

The study showed the densities of wildfire incidence and burnt area, which cover 0.09 number of wildfire incidence and 3.4 hectares forest area burnt per $\mathrm{km}^{2}$ (Table 2). The highest densities of wildfire incidence and burnt area showed in Terai (0.22 number of incidence and 6.4 ha burnt area per $\mathrm{km}^{2}$ ) and comparatively lower incidences in high mountain and high Himalayan regions ( 0.03 number of incidence and 1.0 ha burnt area per $\mathrm{km}^{2}$ ). The second and third wildfire incidence and burnt area densities occurred in the Siwalik and middle mountain regions, which cover 0.16 number of wildfire incidence with 6.3 ha burnt area and 0.09 number of wildfire incidence with 3.5 ha burnt area, respectively. 


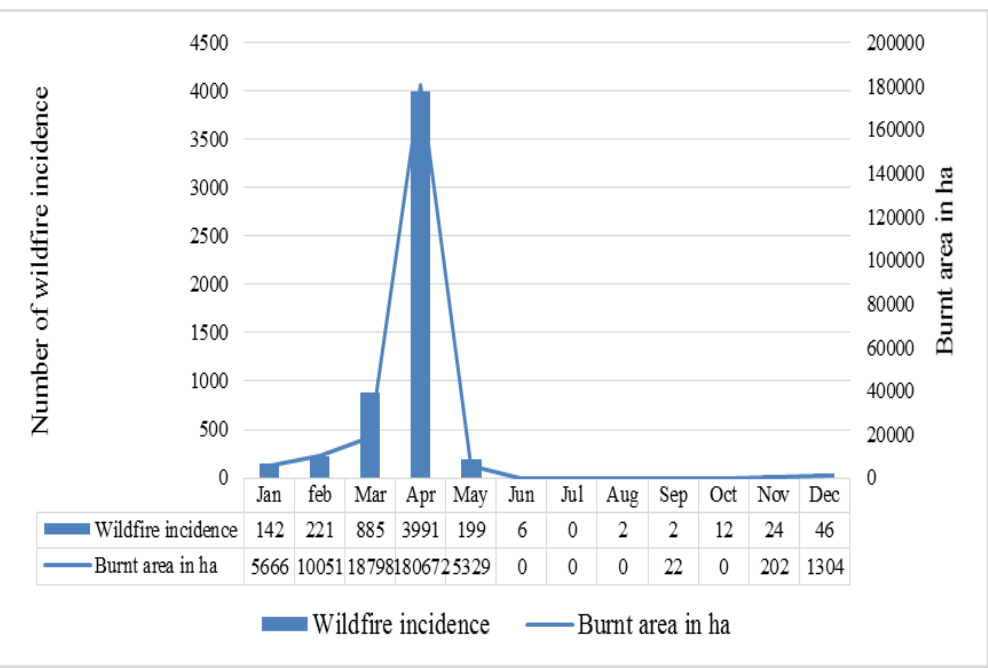

Fig. 4. Monthly based wildfire incidence and burnt area

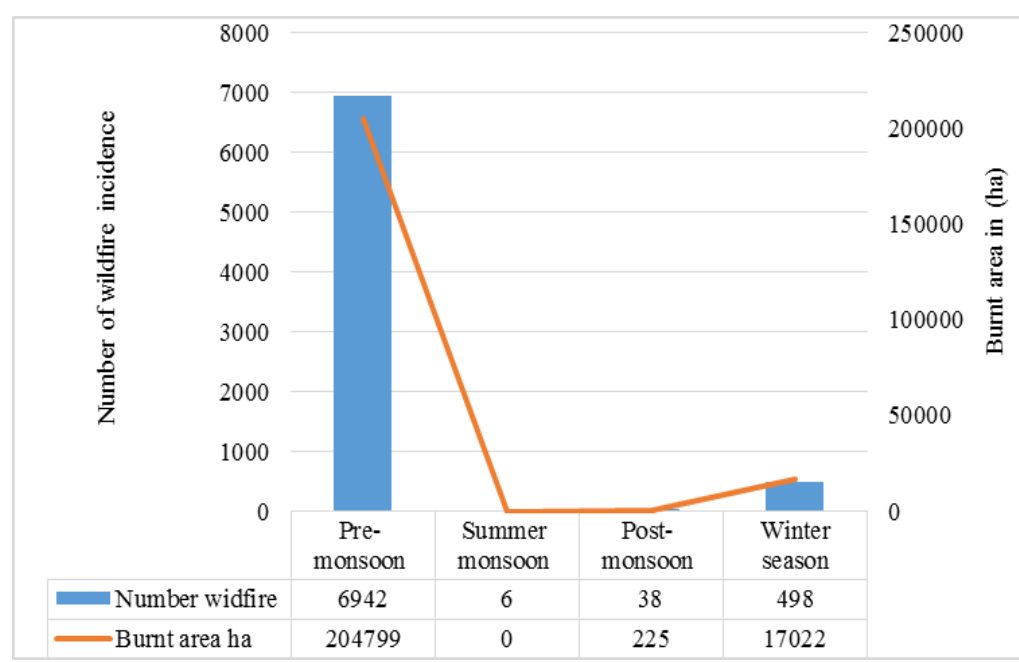

Fig. 5. Seasonal based wildfire incidence and burnt area

Table 1. Wildfire days and densities

\begin{tabular}{|c|c|c|c|c|c|}
\hline Month & Wildfire Days & $\begin{array}{l}\text { Wildfire } \\
\text { Incidence }\end{array}$ & $\begin{array}{l}\text { Burnt Area } \\
\text { (ha) }\end{array}$ & $\begin{array}{c}\text { Average incidence } \\
\text { (number/day) }\end{array}$ & $\begin{array}{c}\text { Average Burnt } \\
\text { (area/day) }\end{array}$ \\
\hline Jan & 24 & 142 & 5666 & 6 & 236 \\
\hline Feb & 25 & 221 & 10051 & 9 & 402 \\
\hline Mar & 19 & 885 & 18798 & 47 & 989 \\
\hline Apr & 24 & 3991 & 180672 & 166 & 7528 \\
\hline May & 14 & 199 & 5329 & 14 & 381 \\
\hline June & 2 & 6 & 0 & 3 & 0 \\
\hline July & 0 & 0 & 0 & 0 & 0 \\
\hline Aug & 0 & 2 & 0 & 0 & 0 \\
\hline Sept & 2 & 2 & 22 & 1 & 11 \\
\hline Oct & 5 & 12 & 0 & 2 & 0 \\
\hline Nov & 14 & 24 & 202 & 2 & 14 \\
\hline Dec & 11 & 146 & 1304 & 4 & 119 \\
\hline Total & 140 & 5630 & 222046 & - & - \\
\hline Average & 12/month & 469/month & 18504/month & 40/day & 1586/day \\
\hline
\end{tabular}


Table 2. Wildfire densities in 2016

\begin{tabular}{|c|c|c|c|c|c|}
\hline Physiographical Region & $\begin{array}{c}\text { Forest Area } \\
\left(\mathrm{km}^{2}\right)\end{array}$ & $\begin{array}{c}\text { Total Wildfire } \\
\text { Incidence }\end{array}$ & $\begin{array}{c}\text { Wildfire } \\
\text { Incidence }\left(\mathrm{km}^{2}\right)\end{array}$ & $\begin{array}{c}\text { Burnt Area } \\
(\mathrm{ha})\end{array}$ & $\begin{array}{c}\text { Burnt Area } \\
\left(\mathrm{ha} / \mathrm{km}^{2}\right)\end{array}$ \\
\hline High Mountain \& Himalayan & 24763.4 & 656 & 0.03 & 25873 & 1.0 \\
\hline Middle Mountain & 23160.94 & 2057 & 0.09 & 81128 & 3.5 \\
\hline Siwalik & 13964.15 & 2236 & 0.16 & 88187 & 6.3 \\
\hline Terai & 4210.82 & 681 & 0.16 & 26858 & 6.4 \\
\hline Total & 66099.31 & 5630 & 0.43 & 222046 & 17.2 \\
\hline Average & & & 0.09 & & 3.4 \\
\hline
\end{tabular}

\section{Wildfire incidences in different land cover types}

Total $66 \%$ of the wildfire incidence occurred in the forest area, indicating the higher wildfire incidence than other land covers. It was followed by grass $(17 \%)$, shrub-land $(10 \%)$ and other lands (6\%) respectively (Fig. 6). The other land, considered as a nearest abandoned land of agriculture were covered by bushes. It showed that forest was highly wildfire risk zone than other land covers in Nepal.

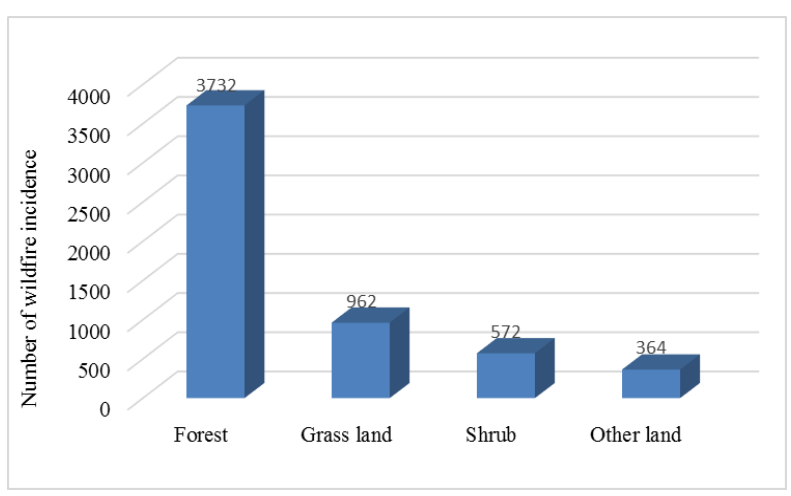

Fig. 6: Wildfire intensity in land cover

\section{Damage and loss}

The research showed the approximately 0.22 million hectares of forest was burned, which cover $3.4 \%$ of the whole forest area of Nepal. The huge forest biomass, forest ecosystem service, and public property were destroyed by wildfire across the country. Total of 2500 cubic feet of highly valuable timber and 12500 cubic feet fuel-wood were lost and damaged. Based on the local market price, the loss of timber and fuel-wood was equivalent to NRs $11,750,000$ (US\$ 107,798). The timber price in the local market was NPR 4500 per cubic feet and fuel-wood NPR 40 per cubic feet. During the time of calculation, the foreign currency exchange rate was 1 USD $=109$ NPR. Besides, the leaf litter, herbs, and shrub were almost completely lost and damaged. The poles and timbers were the least damaged due to surface fire. In addition, there was a noticeable loss of biodiversity, loss of wildlife habitat, loss of fodder and other natural resources with natural regeneration.
Eleven people were killed by wildfire across the country in 2016. They were living closest to the forest and involved in the wildfire control process during the forest fire. Over 100 local people were injured during the wildfire control. A large number of temporary house and domestic animals were damaged during the fire season. There was lack of skill, knowledge, and equipment for preventive and control measures of the wildfire at local level. In addition, large number of wildlife and their habitat were lost and damaged. The forests of Terai, Siwalik and Middle Mountain regions were highly affected by the wildfire. The forest of Surkhet, Bardiya, Dang, Kailali, Kanchanpur, Argakhanchi, Rupandehi Kapilbastu, Nawalparasi, Bara, Parsa, Rautahat, Mahottari, Dhanusa and Sindhuli districts was noticed as the highly affected by wildfire (Matin et al. 2017).

\section{DISCUSSION}

The study focused on the analysis of the wildfire scenario of 2016 and its effects on the forest resources and public property of Nepal. The wildfire in Nepal was recorded abnormally high and its' consequence was found to adversely affect the forest resources and public property. Forests are most susceptible to fire due to the dominance of the fire-prone tropical broad-leaved related vegetation and heavy fuel loads, rising temperatures, and low rainfall. The forest fuel was accumulated in large quantity in the forest because of fewer numbers of forest fire events in the previous year in 2015 (Westerling 2016). Approximately, $72 \%$ wildfire incidence and $81 \%$ burnt area was recorded in the month of April. Moreover, high wildfire events were also detected in March, May and February months and nominal incidence of wildfire noticed in other months. Petoukhov et al. (2018) study showed high-temperature conditions at the surface in that area, causing an increased wildfire hazard in Canada during 2016. According to Upadhyay (2016), wildfire was reported in numerous places across the Indian state of Uttarakhand in 2016. The wildfire incidences were recorded 20,667 during the four months of 2016 basically in the Himalayan foothills and in central and eastern India (Trivedi \& Anupam 2016). During 2016, local, state, federal, and tribal firefighting agencies responded to 6,954 
wildfires that burned 669,534 acres across the entire state of California (Pimlott 2016).

The study showed that a higher wildfire incidence and burnt area occurred in April and none in July and August. It was followed by March, May, and February as second, third and fourth higher wildfire incidence respectively. In an average, $92 \%$ wildfire incidence and burnt area recorded in the pre-monsoon season due to warmer climate and abundant dry fuel. This result was consistent with the research findings of (Matin et al. 2017), which showed the $89 \%$ wildfire occurring during the premonsoon season (March-May) in Nepal. A similar study was done by (Shu \& Kou 2001) which depicted that the highest fire-hit time was in February, March, and April in South and Southwest forest areas in China. Moreover, in central India, higher wildfire was observed during the March and April due to prolonged dry seasons and droughts (Giriraj et al. 2010), which was similar to the result of our research. In 2016, Portugal suffered many fires that burnt over 100,000 hectares of land and contributed significantly to the overall results of the fire season (Knorr et al. 2016). Schaphoff et al. (2016) reported that the current fire-affected area is $20 \%$ and forest lost to stand-replacing fires has also increased in forests in Russia.

Our result recorded 140 wildfire days in 2016. Westerling (2016) study showed 138 days of wildfire in last decade. According to MEFC/India (2017), around 33664 forest fires were detected in India in 2016, which covered 52.4 fire per 1000 square kilometer. Approximately, 55\% of wildfires had risen in December 2016 in India (Jenner 2017). The analysis showed that 11 people were killed and over 100 local people were injured due to the wildfire in Nepal. In 2016, a forest fire was noted in numerous places across the Indian state of Uttarakhand. Seven cases of human fatalities and loss of around Rs 550 crore recorded owing to damages caused by forest fires (MEFC/India 2017). A total of 3,390 civilian deaths and 14,660 fire injuries occurred, which was an increase by $3.4 \%$ compared to the year 2015 and the damaged of $\$ 10.4$ billion worth property was recorded in the United States during 2016 (Hylton 2017).

\section{CONCLUSION}

The wildfire incidence and burnt area were recorded abnormally in 2016 that adversely affected the forest resources and public property of Nepal. The April month and pre-monsoon season showed highest numbers of wildfire incidence and burnt area. Approximately, $3{ }^{\circ} \mathrm{C}$ temperature increased during the summer months over the last few decades. Wildfire days was found to be 2 days longer with a high density of fire incidence and burnt area per $\mathrm{km}^{2}$ in comparison to previous years. Terai region was noticed to record highest wildfire and lowest in High Mountain and High Himalayan. The huge forest resources and its services were lost during this year. In addition, 11 people were killed and over 100 local people were injured in the same year. The findings can be useful to local forest managers, researcher and policymakers as baseline information.

\section{REFERENCES}

Chettri, N., Shakya, B., Thapa, R., Sharma, E. 2008. Status of a protected area system in the Hindu KushHimalayas: an analysis of PA coverage. International Journal of Biodiversity Science \& Management 4: 164-178.

de Groot, W.J., Cantin, A.S., Flannigan, M.D., Soja, A.J., Gowman, L.M. and Newbery, A. 2013. A comparison of Canadian and Russian boreal forest fire regimes. Forest Ecology and Management 294: 23-34.

DFRS. 2015. State of Nepal's forests. Forest Resource Assessment (FRA) Nepal, Department of Forest Research and Survey (DFRS), Kathmandu.

DHM. 2017. Observed climate trend analysis in the districts and physiographic regions of Nepal (19712014). Department of Hydrology and Meteorology, Kathmandu.

Dobremez, J.F. 1972. Mise au Point d'une Methode Cartographique d'etude des montagnes tropicales. Le Nepal Ecologie et phytogeographie. These presente a L'Universite Scientifique at Medicale de Grenoble pour obtenir de Docteur es Sciences, Paris.

Doerr, S.H. and Santín, C. 2016. Global trends in wildfire and its impacts: perceptions versus realities in a changing world, Philosophical Transaction of the Royal Society B 371: 20150345 (1-10).

Fiore, A.M., Naik, V., Spracklen, D.V., Steiner, A., Unger, N., Prather, M., Bergmann, D., CameronSmith, P.J., Cionni, I., and Collins, W.J. 2012. Global air quality and climate, Chemical Society Review 41: 6663-6683.

\section{ftp://ba1.geog.umd.edu/Collection5/TIFF/Win18/}

Giglio, L., Randerson, J.T. and van der Werf, G.R. 2013. Analysis of daily, monthly, and annual burned area using the fourth generation global fire emissions database (GFED4). Journal of Geophysical Research: Biogeosciences 118: 317-328.

Giriraj, A., Babar, S., Jentsch, A., Sudhakar, S. and Murthy, M.S.R. 2010. Tracking fires in India using advanced along track scanning radiometer (A) ATSR data. Remote Sensing 2(2): 591-610.

FAO. 2010. Global forest resources assessment. Report, Food and Agricultural Organization (FAO), Forestry Paper-163 
GoN/MoE. 2010. National adaptation programme of action to climate change. Government of Nepal, Ministry of Environment, Kathmandu, Nepal.

Hansen, J., Ruedy, R., Sato, M. and Lo, K. 2010. Global surface temperature change. Reviews of Geophysics 48(4)RG4004: 1-29.

Hartmann, D.L., Klein Tank, A.M.G., Rusticucci, M., Alexander, L.V., Brönnimann, S., Charabi, Y., Dentener, F.J., Dlugokencky, E.J., Easterling, D.R., Kaplan, A., Soden, B.J., Thorne, P.W., Wild, M. and Zhai, P.M. 2013. Observations: Atmosphere and surface. In: Climate Change: The Physical Science Basis. Contribution of Working Group I to the Fifth Assessment Report of the Intergovernmental Panel on Climate Change.

https://firms.modaps.eosdis.nasa.gov/download/

Hylton, H. 2017. Fire loss in the United States during 2016 report. National Fire Protection Association (NFPA). One-Stop Data Shop 1 Battery march Park Quincy, MA. www.nfpa.org

Jenner, L. 2017. Forest fire numbers rise in India in 2016, fire and smoke. National Aeronautics and Space Administration (NASA).

Kansakar, S.R., Hannah, D.M., Gerrard, J. and Rees, G. 2004. Spatial pattern in the precipitation regime of Nepal. International Journal of Climatology 24:1645-59.

Knorr, W., Arneth, A. and Jiang, L. 2016. Demographic controls of future global fire risk. Nature Climate Change 6(8): 781-785.

Kothawale, D.R., Revadekar, J.V. and Kumar, K.R. 2010. Recent trends in pre-monsoon daily temperature extremes over India. Journal of Earth System Science 119(1): 51-65.

Lynn, J. 2017. Report of eastern Asian fires. Spotted by NOAA/NASA's Suomi NPP Satellite, National Aeronautics and Space Administration (NASA).

Matin, M.A., Chitale,V.S., Murthy, M.S.R., Uddin, K., Bajracharya, B. and Pradhan , S. 2017. Understanding forest fire patterns and risk in Nepal using remote sensing, geographic information system and historical fire data. International Journal of Wildland Fire 26(4): 276-286.

MEF/India. 2011. India state of forest report. Forest Survey of India, Ministry of Environment \& Forests, Dehradun, India. www.fsi.nic.in

MEFC/India. 2017. India state of forest report. Forest Survey of India, Ministry of Environment, Forests \& Climate Change (MEFC), Dehradun, India.
Negi, G.C.S., Samal, P.K, Kuniyal, J.C., Kothyari, B.P., Sharma, R.K., Dhyani, P.P. 2012. Impact of climate change on the western Himalayan mountain ecosystems: an overview. Tropical Ecology 53: $345-$ 356.

Parajuli, A., Chand, D.B., Rayamajhi, B., Khanal, R., Baral, S., Malla, Y. and Poudel, S. 2015. Spatial and temporal distribution of forest fires in Nepal. http://www.forestrynepal.org/images/publications/wf c2015 forest fire nepal.pdf

Parisien, M.A. and Moritz, M.A. 2009. Environmental controls on the distribution of wildfire at multiple spatial scales. Ecological Monographs 79: 127-154.

Petoukhov, V., Petri, S., Kornhuber, K., Thonicke, K., Coumou, D. and Schellnhuber, H. J. 2018. Alberta wildfire 2016: Apt contribution from anomalous planetary wave dynamics. Scientific Reports 8(1): 12375.

Pimlott, K. 2016. Wildfire activity statistics. California Department of Forestry and Fire Protection, Governor State of California.

Pradhan, B., Shrestha, S., Shrestha, R., Pradhananga, S., Kayastha, B. and Pradhan, P. 2013. Assessing climate change and heat stress responses in the TarainRegion of Nepal. Industrial Health 51: 101112.

Randerson, J.T., Chen, Y., Van Der Werf, G.R., Rogers, B.M. and Morton, D.C. 2012. Global burned area and biomass burning emissions from small fires. Journal of Geophysical Research: Biogeosciences 117: G04012. doi:10.1029/2012JG002128

Rohini, P., Rajeevan, M. and Srivastava, A. K. 2016. On the variability and increasing trend of Heat waves over India, Scientific Reports 6: 26153. https://doi.org/10.1038/srep26153

Satendra and Kaushik, A.D. 2014. Forest fire disaster management. National Institute of Disaster Management, Ministry of Home Affairs, New Delhi. Derived from: www.nidm.gov.in

Schaphoff, S., Reyer, C. P., Schepaschenko, D., Gerten, D. and Shvidenko, A. 2016. Tamm Review: Observed and projected climate change impacts on Russia's forests and its carbon balance. Forest Ecology and Management. 361: 432-44.

Shorohova, E., Kneeshaw, D., Kuuluvainen, T. and Gauthier, S. 2011. Variability and dynamics of oldgrowth forests in the circum boreal zone: implications for conservation, restoration and management. Silva Fennica 45:785-806. 
Wildfire dynamics and its effects on the forest resources ....

Shu, L. and Kou, X. 2001. Study of the pattern of special forest fire behavior by using satellite remote sensing. Fire Safety Science 10(3):140-144.

Singh, H., Arora, K., Ashrit, R. and Rajagopal, E.N. 2017. Verification of pre-monsoon temperature forecasts over India during 2016 with a focus on heat wave prediction. Natural Hazards Earth System Sciences 17(9): 1469-1485.

Streets, D.G., Yarber, K.F., Woo, J.-H., and Carmichael, G.R. 2003. Biomass burning in Asia: Annual and seasonal estimates and atmospheric emissions. Global Biogeochemical Cycle 17(4): 1099.
Trivedi and Anupam, A. 2016. Uttarakhand forest fire: loss much more than estimated, say ecologists. Hindustan Times. Dehradun.

Upadhyay, K. 2016. Uttarakhand battles fire crisis. The Hindu. Dehradun. retrieved on 31 August 2018.

Westerling, A.L.R. 2016. Increasing western US forest wildfire activity: sensitivity to changes in the timing of spring. Philosophical. Transactions Royal Society, Biological Science 371: 20150178. 